\title{
Kompendium wiedzy o polskich holownikach, czyli książka, na którą długo czekano Waldemar Danielewicz, Polskie holowniki morskie 1920-2015, Porta Mare Gdynia (Pomorska Oficyna Wydawniczo-Reklamowa), Gdynia 2015, ss. 312
}

W listopadzie 2015 r. światło ujrzała książka Waldemara Danielewicza na Jerzego Drzemczewskiego Porta Mare. Opatrzona przykuwającą wzrok okładką monografia, której autor, marynista pasjonat, wyborny znawca tematyki szeroko pojętej floty pomocniczej, taboru żeglugi przybrzeżnej oraz jednostek operujących na wodach śródlądzia, prezentuje sylwetki ponad 300 „małych mocarzy” - armadę portowych „,koni roboczych”, jak określa tę specyficzną grupę statków, bez której żaden terminal morski nie byłby w stanie efektywnie funkcjonować.

Jak zauważa Autor, holowniki portowe, nazywane często portowo-redowymi, chociaż w publikacji przedstawia się też holowniki gospodarcze i specjalne, zaliczamy do najważniejszych, ale i najbardziej uniwersalnych jednostek floty pomocniczej ${ }^{1}$. Taboru skupiającego mocne, zwrotne, o sta-

1 Próbując sprecyzować, jakie rudymentarne cele stawia się przed flotą pomocniczą Polskiej Marynarki Handlowej, najogólniej można stwierdzić, że jej zasadnicze zadanie zawiera szeroko pojętą obsługa portu. Służbę, która mieści zarówno dbałość o jego bezpieczeństwo, nadzór nad właściwym stanem kanałów i dróg wodnych, jak i intencje zaspakajania niezbędnych potrzeb zaopatrzeniowych zawijających tu frachtowców czy cruiserów. W skład prezentowanej zbiorowości jednostek wchodzą zatem holowniki, lodołamacze, pilotówki, motorówki cumownicze i maklerskie, bunkierki, pogłębiarki i szalandy oraz statki hydrograficzne, ratownicze i pożarnicze. Tabor specjalny z kolei nie ma bezpośrednich powiązań z usługami wobec jednostek innych, jako że służy celom i poru- 
lowej i zwartej budowie statki, których podstawowa aktywność sprowadza się do wspomagania manewrujących (wchodzących lub opuszczających port) jednostek, których zdolność poruszania się na zamkniętych torach wodnych i akwenach, choćby ze względu na gabaryty, nie prezentuje się najlepiej. Inne, niemniej ważkie zajęcie tej części taboru dotyczy wszelkiego rodzaju usług holowniczych: prac na rzecz ruchu tonażu pogłębiarskiego, obsługi niedysponujących własnym napędem bunkierek, barek, dźwigów pływających, pontonów i promów czy współdziałania w akcjach ratowniczych (ściąganie statków z mielizny, holowanie wraków, akces w operacjach pożarniczych). Umocowaną w przepisach zasadą jest też, że w okresie zimy ten sam zespół jednostek zajmuje się kruszeniem i łamaniem lodu ${ }^{2}$. Wspomaga lodołamacze, jeśli takimi zarządzający terminalem dysponują, podczas usuwania zagrożeń, które mogłoby unieruchomić port.

Ujęta $\mathrm{w}$ formę albumu publikacja zawiera zatem merytoryczne wprowadzenie, w którym skrótowo omawia się flotyllę holowniczą w kolejnych przedziałach czasowych (lata 1920-1939, 1945-1960 i 1990-2015), potem znajdziemy kilkaset starannie dobranych, w większości historycznej wymowy, niepublikowanych wcześniej fotografii i bogatych w faktografię biogramów, wreszcie - jest też klarowny podział. W części pierwszej zobrazowano bowiem sylwetki 75, ukazanych w kolorowej wersji jednostek, które aktualnie eksploatowane są w portach i przystaniach naszego wybrzeża. W drugiej zaś, czarno-białej, sięga się do czasów odległych. Dni odzyskania niepodległości, dat, kiedy zapadały decyzje zakupu „Castora” i „Polluxa”, budowy portu wojennego w Pucku i handlowego w Gdyni.

Część pierwsza, która przybliża realia współczesnego pejzażu portowego, uświadamia zarazem w pełni, jak zróżnicowanym taborem posługujemy się obecnie. Jak owa flotylla „małych mocarzy” - patrząc na jej wiek, siłę maszyn, walory eksploatacyjne i stopień nowoczesności - faktycznie wygląda? Nie jest to, niestety, widok budujący. Analizując ów tabor już tylko w kontekście czasu morskiej służby, dat, w których poszczególne statki odbierano ze stoczni, daje się dostrzec, że najlepsze lata ma on już dawno za sobą. Dzięki Danielewiczowi widać bowiem wyraźnie, że - pomimo akceptowalnej kondycji technicznej, regularnych przeglądów i okresowych

czeniom naukowo-badawczym, inspekcyjnym (dozór stref rybołówstwa, ochrony środowiska i granic) czy komunikacyjnym (pozwala na przemieszczanie się po akwenach wewnątrzportowych.

${ }_{2} \mathrm{Z}$ uwagi na to, że obecnie budowane holowniki mają względnie dużą moc maszyn, wzmocnione poszycie i znacznie bardziej masywną konstrukcję stewy dziobowej (dziobnicy), wszystkie one z powodzeniem pełnią funkcję portowych lodołamaczy. 


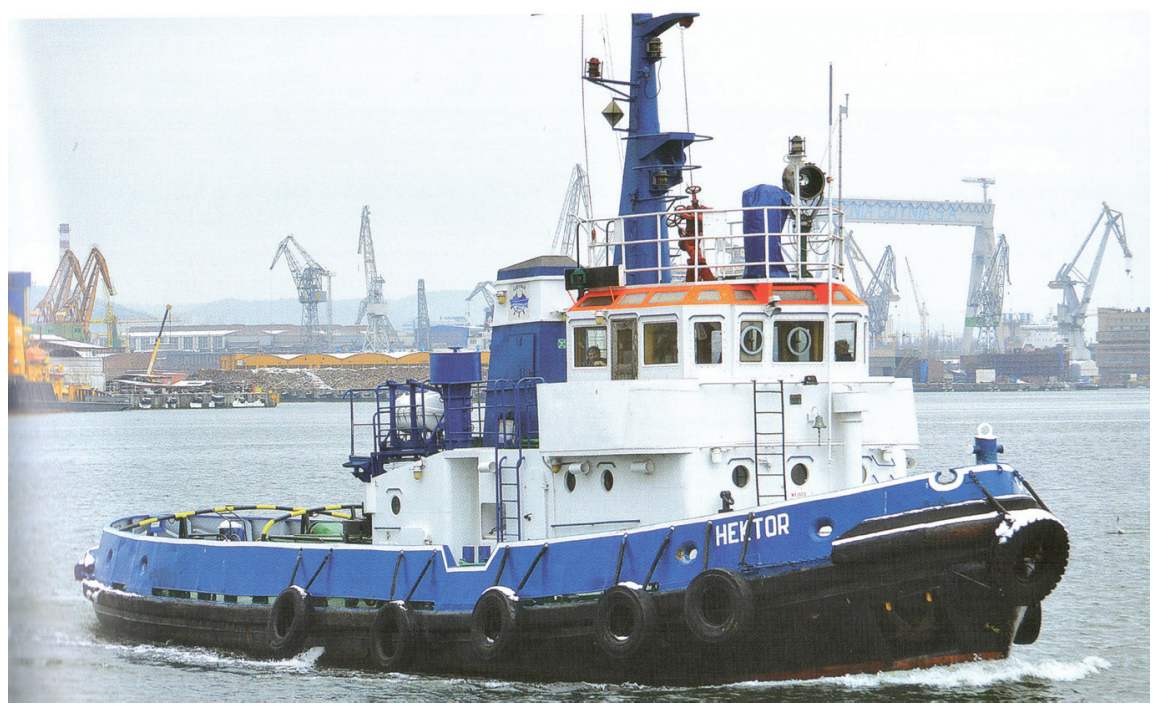

Fot. 1. Holownik „Hektor”. Zbudowany w stoczni gdyńskiej Nauta, wszedł do służby w Zarządzie Portu Gdynia wiosną 1982 r. Od marca 2015 r. właścicielem i armatorem statku jest spółka komandytowa Fairplay Towage Polska, aczkolwiek terenem operacyjnym pozostaje Gdynia

modernizacji, co stanowi rezultat nie tyle, a może nie tylko armatorskiej dbałości, ale i nowych, powiązanych z zaostrzonymi wymogami towarzystwa klasyfikacyjnego przepisów - jest to już tonaż wiekowy. Ilustrują to i potwierdzają liczby. Wartości, z których wynika, że aż 45 (z 75) jednostek zbudowano w latach 60 . i 70. minionego stulecia, $14 \mathrm{w}$ dekadzie kolejnej, a zaledwie $7 \mathrm{w}$ latach 90 . i 6 po $2000 \mathrm{r}$. Nawet godząc się z przyjętą i aprobowaną przez ogół operatorów opinią, że holownik 30-letni pozostaje wciąż w przedziale „wieku średniego” oraz odrzucając trzy jednostki znamionujące poprzednią epokę, których miejscem powinno być muzeum morskie czy galeria archaicznej techniki ${ }^{3}$, trudno postawionej tezie zaprzeczyć.

3 Owe trzy statki to pochodzący z hamburskiej stoczni Maschinenfabrik und Kasselschmiede J.H.N Wichhorst, zbudowany w 1906 r. jako „Max Sötje”, służący wciąż rybakom władysławowskiego Szkunera holownik „Franuś”. Oddany do użytku w 1921 r., powstały w nieznanej stoczni w Königsbergu (Królewcu), przebudowany z parowca, będący aktualnie w gestii armatorskiej gdyńskiego Zakładu Usług Podwodnych i Hydrotechnicznych Neptun, holownik „Okoń” oraz wywodzący się z doków Gdyńskiej Stoczni Remontowej, wzorowany na przedwojennych holownikach poniemieckich, motorowiec „Lucek”. Statek, który zbudowano w 1957 r., a który - jako własność Urzędu Morskiego w Słupsku - stacjonuje w Ustce. 
Przedstawiając i komentując prezentowany przez Danielewicza tabor holowniczy, jaki ogląda się dziś w naszych portach, szczególną uwagę zwracają fragmenty, w których omawia się jednostki ukazujące rozwiązania konstrukcyjne ostatnich lat. Są to holowniki najnowszej generacji wyposażone w stery strumieniowe, pędniki azymutalne, mające wysokoprężne, kompaktowe silniki spalinowe o mocy od kilkuset do kilku tysięcy kilowatów, które zapewniają kilkudziesięciotonowy uciąg ${ }^{4}$ lub 12- czy 13-węzłową prędkość, a nad którymi pieczę powierza się stosunkowo niewielkiej, wysoko kwalifikowanej obsadzie załogowej (zwykle znajduje tam zatrudnienie od trzech do sześciu osób). To prawda, że stanowiących synonim nowoczesności statków nie mamy zbyt wiele, niemniej „dzielność morska, skuteczność manewrowa oraz wysoki poziom uniwersalności i ułatwiającej pracę automatyki podkreślają ponadprzeciętną klasę „Akula”, „Vegi” czy „Virtusa”. Stanowią walory, które podnoszą też rangę portu.

Druga, bardziej obszerna część tomu omawia 235 jednostek, które swego czasu nosiły biało-czerwoną banderę, a które wycofano przed laty, złomując je bądź sprzedając polskim lub obcym kontrahentom. Są tu zatem - oprócz wspomnianych wcześniej unikatowych zdjęć, dołączonych do załączników ilustracji i umieszczonych w ramkach, uaktualnionych, uwidaczniających wielkości charakterystyczne poszczególnych jednostek informacji - bogate w materiał dokumentacyjny objaśnienia i przypisy. Noty, w których Danielewicz - nie ograniczając się do przedstawienia danych zawartych w rocznikach PRS-u, branżowych periodykach czy publikacjach innych autorów - zmierza zdecydowanie dalej. Przywołuje, najczęściej precyzyjnie i gruntownie, nieznane epizody długich i pogmatwanych dziejów statków, które dotąd pozostawały niezbadane. $\mathrm{Z}$ dużym zaciekawieniem odkrywa się zatem okoliczności zakupu przez Departament Morski Ministerstwa Spraw Wojskowych, które w 1920 r. reprezentował major (późniejszy profesor Politechniki Gdańskiej) Aleksander Rylke, holownika „Castor”, postrzega przejścia powiązanej z przemytem do sowieckiej strefy okupacyjnej ludzi pochodzenia żydowskiego parowca o nazwie „Helene” (post-,,Florian”) czy poznaje losy poniemieckiego „Herkulesa”, który w ostatnich dniach sierpnia 1939 r. jako „Albert Forster” wprowadzał do portu gdańskiego ponurej sławy pancernik Kriegsmarine „Schleswig-Holstein”.

${ }^{4}$ Przykładowo należący do gdańskiej spółki WUŻ Port and Maritime Service Ltd, trzynastoletni „Akul”, który zbudowała gdyńska stocznia Damen Shipyard SA, dysponuje możliwością wyłożenia na haku 73 ton przy biegu naprzód i 68 ton przy ruchu wstecz, będąc zarazem najsilniejszym i największym holownikiem, jaki kiedykolwiek operował w polskich portach. 
W części omawiającej holowniki, które stały się już historią, autor powraca też do lat pookupacyjnego mroku - okresu końca lat 40. ubiegłego wieku, kiedy rewindykowano tabor uprowadzony na Zachód, kupowano brytyjski i amerykański demobil, wyciągano z dna zatopione przez najeźdźców wraki, które po odbudowie stawały się istotnym elementem tworzonej od podstaw infrastruktury. Także i tu przedstawia nowe horyzonty wiedzy, wykazuje się dociekliwością, udowadniając, że niebagatelną wagę przywiązuje do historycznych niuansów. Ujawnia, że dotarł do archiwalnych materiałów i źródeł, które dla niezapomnianego Jerzego Micińskiego ${ }^{5}$, marynisty, historyka polskiego shippingu, piszącego blisko pół wieku temu Polskie statki pomocnicze i specjalne 1920-19396 (tam holownikom poświęcono niespełna piątą część książki), okazywały się nieosiągalne.

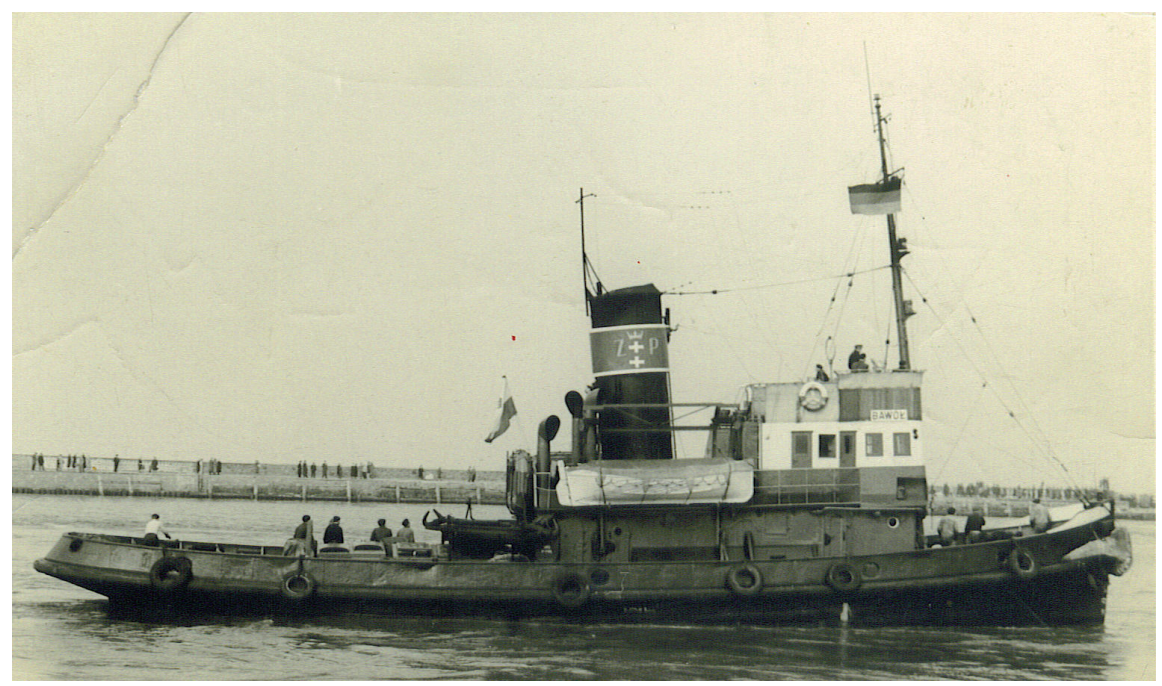

Fot. 2. Holownik „Bawół”. Dysponujący napędem parowym holownik „Bawół” (ex-,,Rechtenfletch”) powstał w 1929 r. w niemieckiej stoczni w Wesermünde-Gestemünde, pod polską banderą znalazł się w kwietniu 1947 r., a złomowany został 31 lat później

5 Zmarły w 1995 r. dziennikarz był historykiem, długoletnim publicystą, redaktorem naczelnym miesięcznika „Morze” oraz autorem książek poświęconych dziejom przedwojennej żeglugi. Ostatnia jego praca to trzytomowe dzieło Księga statków polskich 1918-1945, które ukazało się już po śmierci autora.

${ }^{6}$ Niewznawiana w latach późniejszych publikacja wydana została jako tom drugi Prac Muzeum Morskiego w Gdańsku, ukazując się nakładem Wydawnictwa Morskiego w Gdyni w 1967 r. 
Powiązane z przygotowaniem publikacji do druku prace rozpoznawcze, szersze kwerendy oraz zbieranie fotografii i danych będących deskrypcją wielkości charakterystycznych poszczególnych jednostek zajęły Waldemarowi Danielewiczowi około 15 lat. W tym czasie autor dotarł do różnego charakteru archiwów ${ }^{7}$ i zasobów kilkudziesięciu prywatnych kolekcjonerów marynistyki (ich lista znajduje się na końcu książki), gromadząc ponad 650 zdjęć. Sięgnął do rejestrów brytyjskiego Lloyda i PRS-u. Podjął korespondencyjny kontakt i korzystał z pomocy takich badaczy dziejów floty niemieckiej jak (nieżyjący już) Erich Mahlo z Dessau, Andreas von Mach z Ingolstadt czy Berndt Schwarz z Halle, który w 2012 r.u wydał swoje kolejne dzieło Binnenschiffe Zwischen Ostpreussen und Schleisen ${ }^{8}$. Innym kluczowym obszarem głębszych peregrynacji - jak przyznał Danielewicz - stało się staranne opracowanie Hansa Jürgena Aberta Die Deutsche Handels-Marine 1870-1970 (Die Lebensläufe der Dampf-undMotor Schiffe über 100 BRT) ${ }^{9}$ oraz wydane w Cuxhaven w 1987 r. studium Kurta Pittelkowa Schmelzkopf Reinhartn - Heimathafen Stettin. Cennym źródłem dokumentacyjnym były też monografie polskich autorów. Dorobek pisarski Jerzego Micińskiego, Stefana Kolickiego, Jana Kazimierza Sawickiego, Bohdana Hurasa, Marka Twardowskiego czy Krzysztofa Gogola, ale też zbiory materiałów z firm armatorskich i specjalistyczne, prezentujące renomę fachowości magazyny naukowo-techniczne, ukazujące się w Niemczech i Holandii „Schiffahrt International”, „Sleep \& Duwvaart” i „Strandgut” czy redagowane w kraju - tu wymieńmy te najważniejsze: miesięcznik „Budownictwo Okrętowe”"10 $\mathrm{i}$ - od niedawna rocznik Polskiego Towarzystwa Nautologicznego - „Nautologia”.

Autor prezentowanego albumu (mieszkaniec Gdańska, rocznik 1953) to postać w środowisku historiografów szeroko pojętej żeglugi doskonale znana. Długoletni marynarz i oficer, szef Inspektoratu Żeglugi Śródlądowej w Gdańsku, do niedawna główny nawigator Żeglugi Gdańskiej, ale też aktywny, ceniony w środowisku publicysta. Autor dziesiątek materiałów i elaboratów, które ukazywały się na łamach nieistniejącego już miesięcznika „Morze”, wciąż edytowanych periodyków „Morza, Statki i Okręty”,

7 Oprócz archiwów armatorskich i osób prywatnych, Autor korzystał też z zasobów Archiwum Akt Nowych w Warszawie oraz Archiwum Państwowego w Gdańsku (oddział w Gdyni).

${ }^{8}$ Edytorem była oficyna Strandgut Verlag, Cuxhaven.

9 Pracę wydano w Ratzeburgu w 1987 roku.

${ }_{10}$ Pismo od roku 1999 po fuzji z miesięcznikiem „Technika i Gospodarka Morska” nosiło nazwę „Budownictwo Okrętowe i Gospodarka Morska”, a jego wydawcą była gdańska spółka Okrętownictwo i Żegluga. W roku 2003 edycja periodyku została zawieszona. 
„Morza i Okręty” i „Wodniak Bydgoski” czy tekstów zamieszczanych na stronie internetowej „Żegluga śródlądowa - wczoraj, dziś i jutro”, której jest współtwórcą i redaktorem. Danielewicz jest również inicjatorem przygotowanego dla niemieckiego czasopisma „Strandgut” tomu Schiffe auf der Weichsel 1827-1945, współautorem opracowań (będących częścią encyklopedii okrętów wojennych) Pancerniki kieszonkowe typu Deustchland i Krążowniki typu K, a także opublikowanej niedawno (wraz z Ryszardem Kowalskim i Cezarym Wawrzyńskim) książki 100 lat żeglugi pasażerskiej na Kanale Ostróda-Elblą 1912-2012. Aby listę dokonań autora przedstawić nieco szerzej, dopiszmy też rolę konsultanta historyczno-żeglugowego studium Marka Sandeckiego o tytule Włocławek nad Wisła. Żegluga od czasów najdawniejszych do końca ery parowców, wydanego w ubiegłym roku, oraz status stałego współpracownika czasopism o tematyce morskiej.

Książka będąca świadectwem ważnego etapu tworzenia się Polski Morskiej, którą edytor opatrzył sygnalną sentencją „Ocalić od zapomnienia", była wypatrywana od lat. Czynili to marynistyczni fascynaci, którzy szukają dróg poszerzenia wiedzy o tej grupie taboru. Oczekiwały jej osoby zawodowo powiązane z morzem i jednostkami floty pomocniczej, a więc niemałe gremium szyprów, obsad załogowych i członków nabrzeżnej obsługi. Ludzie, którzy są immanentną składową opisywanych historii, tłem ukazujących się tu „małych mocarzy”, ale i swoistą wspólnotą, której ten warty uwagi tom zadedykowano. 